\title{
Pengembangan Media Tiga Dimensi Kontekstual Berbahan Dasar Barang Bekas untuk Siswa Kelas IV SD
}

\author{
Ainun Jariah ${ }^{1 *}$, A. Hari Witono', Baiq Niswatul Khair ${ }^{1}$ \\ 'Program Studi Pendidikan Guru Sekolah Dasar, Universitas Mataram, Mataram, Indonesia \\ "Corresponding author: ainunjariah0306@gmail.com
}

\begin{abstract}
Abstrak: Penelitian ini bertujuan untuk mengetahui pengembangan media pembelajaran tiga dimensi kontekstual berbahan dasar barang bekas untuk siswa kelas IV SD. Jenis penelitian yang digunakan pada penelitian ini adalah penelitian pengembangan yang telah dikembangkan oleh Dick and Carry (1996). Adapun model pengembangan yaitu ADDIE (Analysis, Design, Development, Implementation, Evaluation). Subyek yang digunakan dalam penelitian ini yaitu terdiri dari 6 orang siswa kelas IV di SDN 10 Mataram. Hasil penelitian menunjukkan bahwa media tiga dimensi kontekstual berbahan dasar barang bekas yang telah dikembangkan sudah memenuhi kriteria sangat layak dengan memperoleh nilai persentase $98 \%$ dari ahli media dan ahli materi memperoleh nilai persentase 93\% dengan kriteria sangat layak. Sedangkan dari respons siswa memperoleh nilai $95 \%$ dan sudah memenuhi kriteria sangat layak untuk digunakan. Dengan demikian dapat disimpulkan bahwa media tiga dimensi kontekstual berbahan dasar barang bekas sudah sangat layak untuk digunakan kepada siswa kelas IV SD pada materi siklus hidup kupu-kupu.
\end{abstract}

Kata Kunci: media, kontekstual, barang bekas, sekolah dasar

Abstract: This study aims to see the development of contextual three-dimensional instructional media made from used goods for fourth grade elementary school students. The type of research used in this research is development research that has been developed by Dick and Carry (1996). The development model is ADDIE (Analysis, Design, Development, Implementation, Evaluation). The subjects used in this study consisted of 6 grade IV students at SDN 10 Mataram. The results showed that the three-dimensional contextual media made from used goods that had been developed had met the very feasible criteria by obtaining a percentage value of $98 \%$ from media experts and material experts with a percentage value of 93\% with very feasible criteria. Meanwhile, from the student's response, the score is $95 \%$ and it has met the very appropriate criteria for use. Thus, it can be ignored that the contextual three-dimensional media made from used goods is very suitable for use by fourth grade elementary school students on butterfly life cycle material.

Keywords: media, contextual, used goods, elementary school

\section{PENDAHULUAN}

Pane \& Darwis (2017: 337) menyatakan bahwa pembelajaran pada hakikatnya adalah suatu proses yang mengatur, mengorganisasikan lingkungan yang ada di sekitar siswa sehingga dapat menumbuhkan dan mendorong siswa melakukan proses belajar. Pembelajaran juga dapat dikatakan sebagai proses yang dapat memberikan bimbingan atau bantuan kepada siswa dalam melakukan proses belajar. Minsih \& Galih (2018: 21) menyatakan bahwa peran guru sangat penting dalam kegiatan pembelajaran di dalam kelas. Dalam mengelola kelas guru perlu menciptakan suasana gembira atau menyenangkan di lingkungan sekolah melalui komunikasi intens dan penggunaan media pembelajaran. Dengan menjalin interaksi dan menggunakan media 
pembelajaran, maka guru dapat mengarahkan siswa dengan lebih mudah untuk mendorong dan memotivasi belajar siswa.

Siswa kelas IV SD pada hakikatnya memiliki karakteristik yang berbeda-berbeda, yaitu masih suka bermain, menyukai hal-hal yang berhubungan dengan pengalaman pribadi dan sangat aktif dalam proses pembelajaran. Media yang digunakan oleh guru hanya terbatas, seperti media gambar dan media dua dimensi. Oleh karena hal itu hendaknya guru mengembangkan model pembelajaran yang dapat menarik perhatian siswa dan meningkatkan pemahaman belajar bagi siswa. salah satunya yaitu guru dapat membuat media pembelajaran yang menarik serta sesuai dengan karakteristik siswa, sehingga pembelajaran lebih terarah dan menyenangkan.

Pada hakikatnya media pembelajaran adalah alat, metode dan teknik yang digunakan dalam rangka lebih mengefektifkan komunikasi antar guru dan siswa dalam proses pendidikan dan pengajaran di sekolah (Hamalik, 1989: 12). Selain itu Hasniandah (2015: 36) menyatakan media pembelajaran sangat berperan penting karena dapat memberikan dampak positif bagi siswa, baik yang berkenaan dengan proses perkembangan otak maupun berhubungan dengan kreativitas. Jadi dapat disimpulkan bahwa media pembelajaran merupakan suatu alat yang digunakan oleh guru untuk menyampaikan materi pelajaran dalam menunjang proses belajar siswa.

Menurut Daryanto (2010: 30) bahwa media tiga dimensi kontekstual berbahan dasar barang bekas memiliki kelebihan dan kekurangannya. Kelebihan dari medianya yaitu dapat memberikan pengalaman secara langsung, penyajian secara konkret, membantu wujudkan realita yang dapat dilihat dan diraba, sederhana penggunaan dan pemanfaatannya dan mudah didapatkan. Sedangkan kekurangan dari medianya yaitu harganya mahal, membutuhkan keterampilan dalam membuatnya dan penyimpanannya membutuhkan ruang khusus.

Menurut Daryanto (2016: 29) media tiga dimensi kontekstual berbahan dasar barang bekas merupakan media yang dapat diamati secara langsung dalam kehidupan sehari-sehari dan terbuat dari barang bekas di lingkungan sekitar. Barang bekas yang digunakan seperti mika, plastik, sedotan, batok kelapa, cat warna, styrofoam, kertas HVS A4, kertas manila, lidi dan kawat. Penggunaan lingkungan sekitar sebagai media pembelajaran seperti lingkungan sosial, lingkungan alam, dan lingkungan buatan sangat membantu dalam proses belajar mengajar, baik dituangkan dalam audio visual maupun secara langsung sehingga siswa memperoleh pengetahuan dan pemahaman (Susanto, 2013: 138).

Adapun media pembelajaran yang dikembangkan dalam penelitian ini yaitu media tiga dimensi kontekstual berbahan dasar barang bekas untuk siswa kelas IV SD pada materi siklus hidup kupu-kupu. media tiga dimensi kontekstual berbahan dasar barang bekas berbentuk objek nyata yang dapat dilihat dan diamati secara langsung dengan menggunakan bahan yang memanfaatkan barang bekas, seperti mika, plastik, sedotan, batok kelapa, cat warna, styrofoam, kertas HVS A4, kertas manila, lidi dan kawat. Materi yang digunakan yaitu siklus hidup kupukupu.

Berdasarkan paparan di atas, dapat disimpulkan bahwa penggunaan media pembelajaran sangat berperang penting dalam menunjang proses pembelajaran khususnya pada mata pelajaran Ipa yang dapat memberikan pengalaman secara langsung bagi siswa. oleh karena itu perlu mengetahui bentuk dan desain media tiga dimensi kontekstual berbahan dasar barang bekas yang akan dikembangkan untuk siswa kelas IV SD pada materi siklus hidup kupu-kupu.

\section{METODE PENELITIAN}

Metode penelitian yang digunakan penelitian ini yaitu metode penelitian dan pengembangan (Research and Development) yang digunakan untuk menghasilkan suatu produk. Adapun desain penelitian ini menggunakan model ADDIE (Analysis, Design, Deveopment, Implementation and Evaluation). Penelitian ini dilaksanakan pada bulan januari-februari tahun 2021 di kelas IV SD. Tempat penelitian yaitu di SDN 10 Mataram. Subyek yang digunakan penelitian ini yaitu 6 orang siswa kelas IV SD. Teknik pengumpulan data yang digunakan yaitu wawancara dan angket dan instrumen pengumpulan data yaitu angket. Teknik analisis data yang 
digunakan dalam penelitian ini adalah deskriptif kuantitatif dengan menggunakan skala likert dengan rentang skala 1-4. Spesifikasi media tiga dimensi kontekstual berbahan dasar barang bekas yaitu berbentuk objek nyata yang dapat dilihat dan diamati secara langsung dengan menggunakan bahan berupa mika, plastik, sedotan, batok kelapa, styrofoam, kertas HVS A4, kertas manila, lidi dan kawat, dan menggunakan ukuran kotak yang terbuat dari mika dengan ukuran $60 \mathrm{~cm} \times 40 \mathrm{~cm}$.

\section{HASIL DAN PEMBAHASAN}

Hasil penelitian pada tahap (Analysis) ditemukan permasalahan dasar mengenai proses pembelajaran yang ada di kelas IV SD yang digunakan oleh guru khususnya untuk pembelajaran IPA. Berdasarkan hasil wawancara dengan guru wali kelas IV SD, bahwa media pembelajaran yang digunakan yaitu media gambar dan media dua dimensi. Oleh karena itu peneliti memberikan solusi sebagai alternatif untuk perlunya mengembangkan media yang inovatif sehingga dapat mempermudah siswa dalam memahami materi pembelajaran. Salah satunya yang akan dikembangkan oleh peneliti yaitu pengembangan media tiga dimensi kontekstual berbahan dasar barang bekas untuk siswa kelas IV SD. Adapun beberapa tahapan analisis ini yaitu analisis kebutuhan (media pembelajaran), analisis siswa dan analisis proses pembelajaran.

Selanjutnya tahap (Design) yaitu tahap perancangan media tiga dimensi kontekstual berbahan dasar barang bekas yang akan dikembangkan. Adapun beberapa langkah-langkah perancangan media ini yaitu menentukan ukuran media, pemilihan latar/background, menentukan konsep materi dan spesifikasi serta bentuk/tampilan media. Adapun aplikasi yang digunakan untuk menentukan konsep dalam mengembangkan media pembelajaran ini yaitu Photoshop CS3.

Tahap (Development) yaitu tahap untuk menghasilkan suatu produk media yang akan dikembangkan. Tahap ini dilakukan untuk mengetahui saran atau masukan yang diberikan oleh para ahli terkait media tiga dimensi kontekstual berbahan dasar barang bekas. Adapun para ahli ini diberikan 2 validator yaitu validasi ahli media dan validasi ahli materi. Berikut hasil validasi ahli media dan validasi ahli materi dapat dilihat pada Gambar 1.

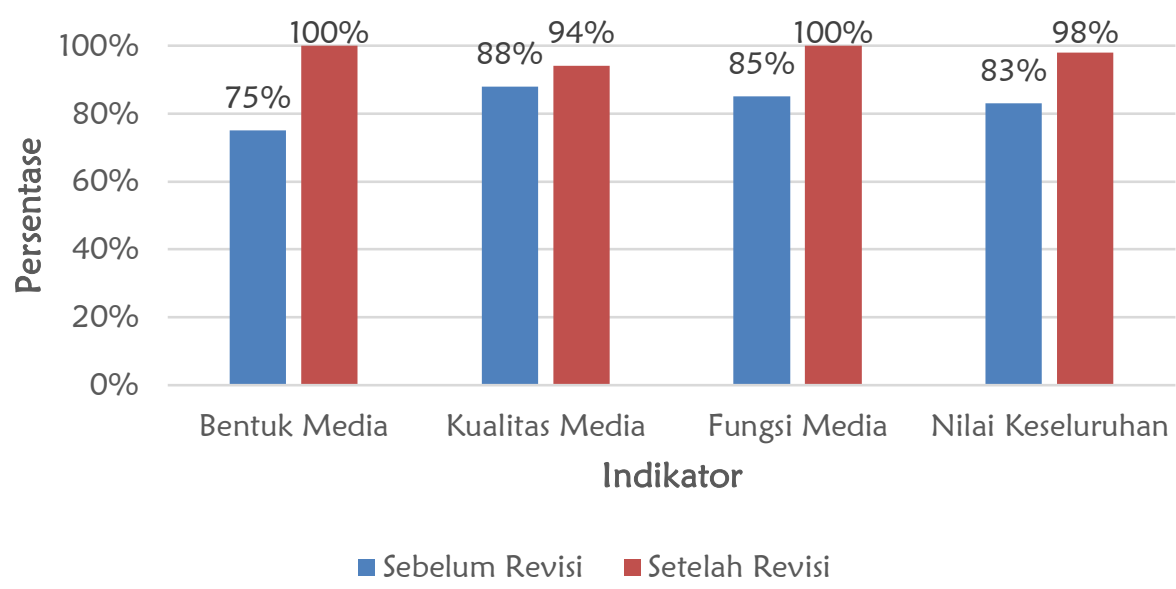

Gambar 1. Hasil Validasi Ahli Media Sebelum dan Sesudah Revisi

Berdasarkan hasil Gambar 1 dapat dijelaskan, bahwa uji ahli media sebelum direvisi mendapat nilai persentase $83 \%$ dan dinyatakan "sangat layak" sedangkan uji ahli media sesudah direvisi mendapat nilai persentase $98 \%$ dan dinyatakan "sangat layak". Hasil penilaian uji ahli media tiga dimensi kontekstual berbahan dasar barang bekas secara keseluruhan sudah sangat layak dan dapat digunakan. Namun ada beberapa yang perlu direvisi media tersebut sesuai kritik saran dari validator.

Selanjutnya adapun perbandingan antara media tiga dimensi kontekstual berbahan dasar barang bekas sebelum direvisi dan sesudah revisi antara lain: 


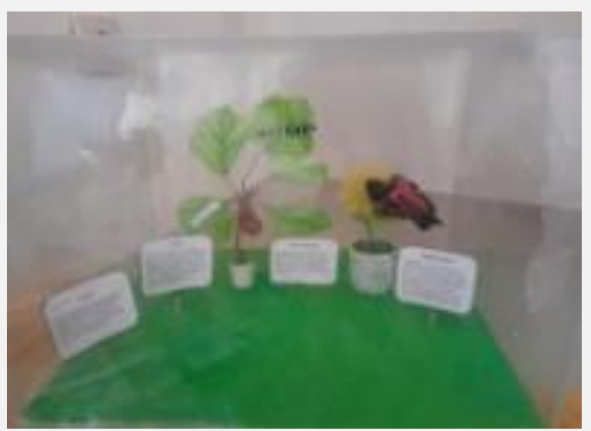

(a)

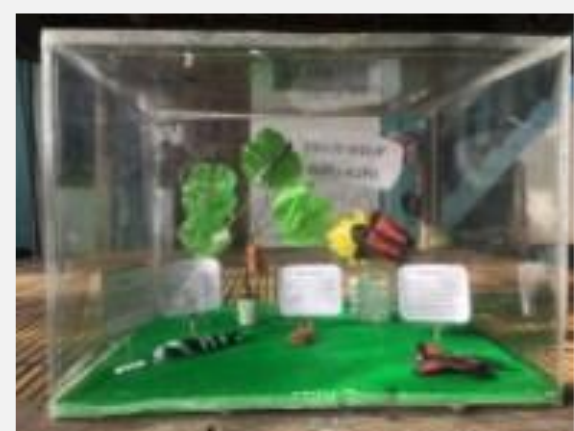

(b)

Gambar 2. Media hasil pengembangan (a) sebelum revisi, dan (b) setelah revisi. (Sumber: dokumentasi penulis, 2021).

Setelah media pembelajaran tiga dimensi kontekstual berbahan dasar barang bekas sudah di uji ahli pada validatornya sesuai saran dan kritikan. selanjutnya media tersebut sangat layak dan dapat digunakan.

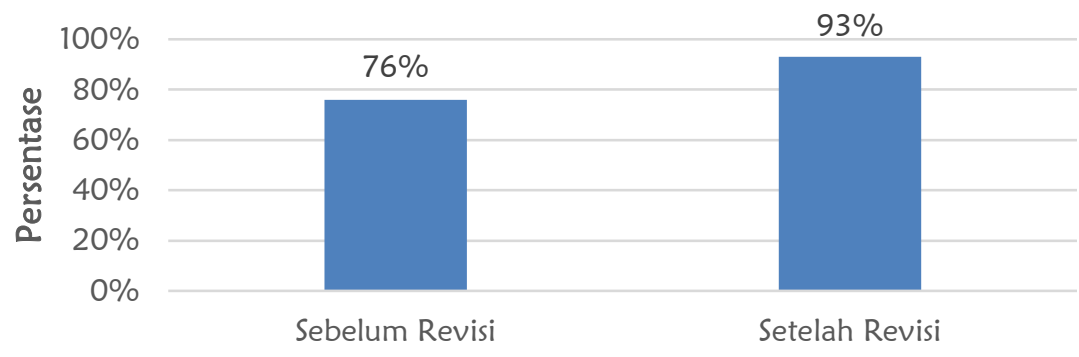

Validasi oleh Dosen \& Guru

Gambar 3. Hasil Validasi Ahli Mater Sebelum dan Sesudah Revisi

Berdasarkan hasil pada Gambar 3 dapat dijelaskan, bahwa uji ahli materi sebelum direvisi mendapat nilai persentase $76 \%$ dan dinyatakan "layak" sedangkan uji ahli media sesudah direvisi mendapat nilai persentase $93 \%$ dan dinyatakan "sangat layak". Hasil penilaian uji ahli materi keseluruhan sudah sangat valid dan dapat materi tersebut dapat digunakan. Namun ada beberapa yang perlu direvisi materi tersebut sesuai kritik saran dari validator.

Selanjutnya tahap (Implementation) yaitu tahap untuk uji coba kelompok kecil kepada 6 orang siswa kelas IV SD. Uji coba kelompok kecil bertujuan untuk mengetahui respons siswa terhadap media tiga dimensi konstektual berbahan dasar barang bekas. Adapun hasil respons siswa dapat dilihat pada Gambar 4.

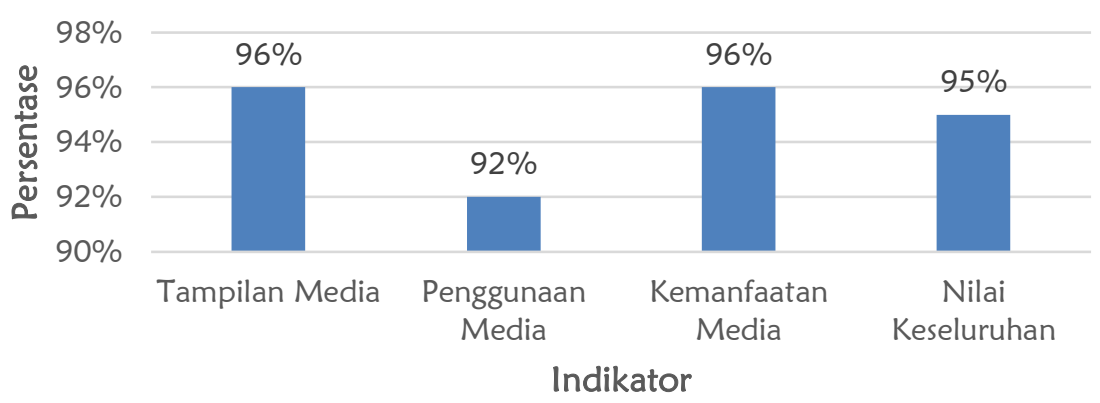

Gambar 4. Respons siswa terhadap media yang dikembangkan 
Berdasarkan Gambar 4 dapat dilihat, bahwa presentase nilai rerata dari pada tampilan media sekitar 96\%, penggunaan media sekitar 92\%, kemanfaatan media sekitar $96 \%$ dan total nilai rata-rata keseluruhan sekitar 95\%. Jadi, secara keseluruhan dari respon siswa terhadap media tiga dimensi kontekstual berbahan dasar barang bekas untuk siswa kelas kelas IV SD yang telah dikembangkan sudah dinyatakan "sangat layak" untuk digunakan dalam proses pembelajaran IPA pada materi siklus hidup kupu-kupu.

Selanjutnya tahap (Evaluation) yaitu tahap untuk mengukur ketercapaian terhadap pengembangan media tiga dimensi kontekstual berbahan dasar barang bekas. Evaluasi ini digunakan untuk mengetaui kelayakan media tiga dimensi kontekstual berbahan dasar barang bekas yang dikembangkan. Berdasarkan hasil penilaian akhir dari uji validasi media, uji validasi ahli materi oleh validator dan respon siswa dapat dilihat pada pada Gambar 5.

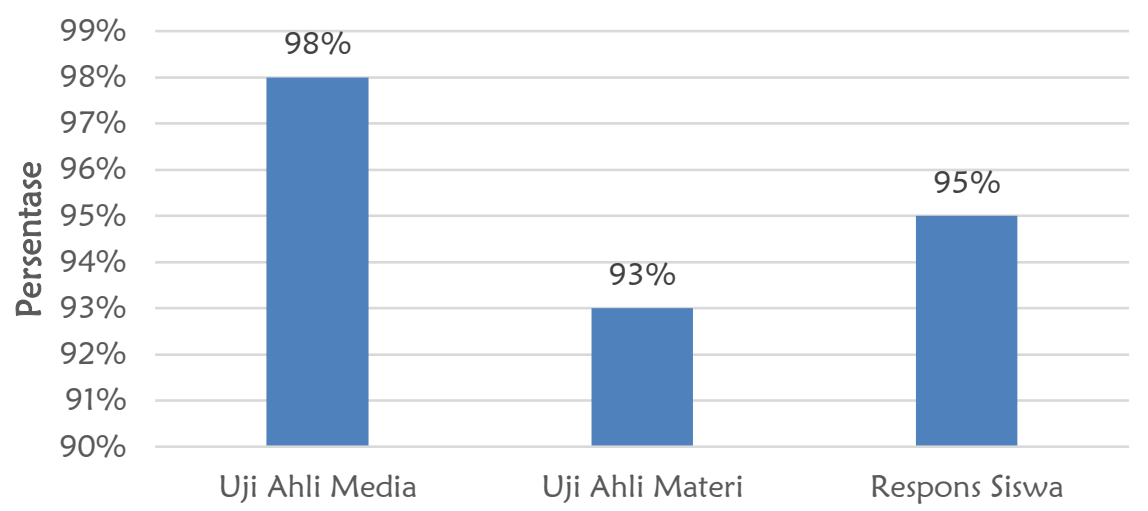

Gambar 5. Hasil penilaian akhir media yang dikembangkan

Berdasarkan hasil penilaian yang terdapat pada gambar diagram di atas, bahwa penilaian akhir terhadap uji ahli media mendapat nilai presentase sekitar 98\%, uji ahli materi mendapat nilai presentase sekitar $93 \%$ dan respon siswa mendapat nilai presentase $95 \%$. Jadi, ketiga penilaian akhir dari uji ahli media, uji ahli materi dan respon siswa terhadap media tiga dimensi kontekstual berbahan dasar barang bekas sudah sangat layak digunakan untuk proses pembelajaran IPA pada materi siklus hidup kupu-kupu.

\section{KESIMPULAN}

Berdasarkan hasil penelitian pengembangan media tiga dimensi kontekstual berdasarkan barang bekas untuk siswa kelas IV SD dinyatakan "sangat layak" digunakan. Hasil nilai akhir yang didapat dari uji ahli media memproleh nilai presentase 98\%, untuk uji ahli materi memperoleh nilai presentase $93 \%$ dan respon siswa memperoleh nilai presentase $95 \%$. pengembangan media tiga dimensi kontekstual berbahan dasar barang bekas dikemas dalam bentuk tampilan lingkungan sekitar dengan menggunakan kotak yang terbuat dari mika plastik dengan bahan barang bekas dan belum ada latihan soal didalamnya. Saran bagi peneliti selanjutnya dapat mengembangkan media yang dikemas dalam bentuk digital dan mendesain menggunakan aplikasi CoreIDRAW serta diberikan beberapa latihan soal untuk siswa agar telihat lebih aktif.

\section{UCAPAN TERIMA KASIH}

Peneliti mengucapkan terimakasih kepada dosen pembimbing yang telah meluangkan waktu untuk membimbing peneliti hingga terselesainya artikel ini. Ucapan terimakasih juga disampaikan kepada kepala sekolah serta guru-guru di SDN 10 Mataram yang telah terlibat aktif selama kegiatan penelitian.

\section{DAFTAR PUSTAKA}

Arikunto. S. 2013. Prosedur Penelitian Suatu Pendekatan Praktik. Jakarta: Rineka Cipta 
Arini, W \& Lovisia, E. 2019. Respon Siswa Terhadap Alat Pirolisis Sampah Plastik Sebagai Media Pembelajaran Berbasis Lingkungan di SMP Musi Rawas. Jurnal Thabiea. Vol 2(2)

Arsyad, Azhar. 2014. Media Pembelajaran. Jakarta: PT Raja Grafindo Persada

Arsyad, Azhar. 2017. Media Pembelajaran. Jakarta: PT Raja Grafindo Persada

Aryasa, G. B. M dkk. 2017. Pengembangan Media Pembelajaran Teknik Dasar Tendangan Pencak Silat dengan Kartu Bergambar. Jurnal PendidikanJasmani, Kesehatan, dan Rekreasi. Vol 8(2).

Asyhari, A. 2016. Pengembangan Media Pembelajaran Berupa Buletin dalam Bentuk Buku Saku untuk Pembelajaran Ipa Terpadu. Jurnal IImiah Pendidikan Fisika. Vol 05(1)

Buzan, T. 2006. Buku Pintar Mind Map. Jakarta: Gramedia Pustaka Utama.

Cahyadi, A \& Sauqy. 2019. Pengembangan Media dan Sumber Belajar. Serang Baru: Laksita.

Daryanto. 2016. Media Pembelajaran. Yogyakarta: Gava Media

Daryanto. 2010. Media Pembelajaran. Yogyakarta: Gava Media

Hamalik, O. 1989. Media Pendidikan. Bandung: Citra Aditya.

Hasnindah. 2015. Media Pembelajaran Kreatif. Jakarta: Luxima Metro Media.

Istialina. 2016. Pemanfaatan Lingkungan Sebagai Sumber Belajar Pada Subtema

Hewan dan Tumbuhan di Lingkungan Rumahku Kelas IV SD Negeri 3 Jeumpa Kabupaten Bireuen. Jurnal Ilmiah Mahasiswa Prodi PGSD. Vol 1(1).

Minsih, G. A. 2018. Peran guru dalam Pengelolaan Kelas. Jurnal Profesi Pendidikan dasar. Vol 5(1)

Mulyatiningsih, Endang. 2011. Riset Terapan Bidang kependidikan \& Teknik.Yogyakarta: UNY Press.

Nomleni, F. T \& Manu, T. S. N. 2018. Pengembangan Media Audio Visual dan Alat Peraga dalam Meningkatkan Pemahaman Konsep dan Pemecahan Masalah. Jurnal Pendidikan Dan Kebudayaan. Vol 8(3).

Pane, A \& Darwis, M. 2017. Belajar dan Pembelajaran. Jurnal Kajian Ilmu-ilmu islam. Vol 3(2).

Puspita, L. 2019. Pengembangan Modul Berbasis Keterampilan Proses Sains Sebagai Bahan Ajar dalam Pembelajaran Biologi. Jurnal Inovasi Pendidikan IPA. Vol 5(1)

Sanjaya. 2011. Perencanaan Dan Desain Sistem Pembelajaran. Jakarta: Kecana Prenada Media Group

Sugiyono. 2018. Metode Penelitian Kuantitatif, Kualitatif dan R\&D. Bandung: Alfabeta

Susanto, A. 2013. Teori Belajar \& Pembelajaran di Sekolah Dasar. Jakarta: Prenada Media Group

Suprihartin, S. 2015. Upaya Guru dalam Meningkatkan Motivasi Belajar Siswa. Jurnal Pendidikan Ekonomi. Vol 3(1) 